\title{
CONTENDING VISIONS OF LOCAL AGRICULTURE IN A NON-AGRICULTURAL STATE: FOOD SOVEREIGNTY IN SINGAPORE
}

\author{
Hyejin Kim
}

What do calls for food sovereignty look like in a context with little agriculture and limited opportunities for resistance? Despite the small number of producers, the lack of overt resistance, and the absence of ties to the global food sovereignty movement, food activists in Singapore articulate a quiet but radical critique of how the state manages globalization. This critique contains elements of a food sovereignty movement in Singapore. This movement faces two sets of challenges. First, the state's control over resources allows for mainstream visions of agriculture to gain greater support and places food sovereignty activists at the mercy of government. Second, commercial pressures raise obstacles to making farming an attractive vocation or hobby for Singaporeans. This example provides a window onto subtle battles over the management of a society's entanglement in global production networks.

Keywords: Southeast Asia, food sovereignty, local agriculture, agricultural technology, global food industry.

\section{Introduction}

Movements to assert local control over food production have emerged across the globe, in wealthy consumer centers and in poorer agricultural regions (Andree et al. 2014; Edelman 2014; McMichael 2014). Diverse motivations drive these movements, from fears of food price fluctuations to concerns about food safety and the environmental impact of production processes. Whatever the motivation, movements for 'food sovereignty' or 'food democracy' are responses to global agri-food networks that shift power away from communities and public authority and toward powerful corporate actors (Di Dio 2012; Lang and Heasman 2004; Menser 2014; Patel 2009). Producers and consumers of food in many parts of the world find themselves frustrated with the loss of power, and have sought ways to regain it. An examination of responses to the globalization of food production is, therefore, a case study in the way globalization more generally tends to undermine sovereignty and provoke collective responses (Grinin 2012).

Singapore is an intriguing site for investigating movements to support local food production. Most research on food sovereignty examines the activities of agricultural communities in the developing world, or affluent Westerners who have sought alternative lifestyles (e.g., Herrera et al. 2015; Navin and Dieterle 2018). In recent years, a set of farmers, gardening enthusiasts, social entrepreneurs, and activists in Singapore have begun to advocate for expanded local control over agriculture. On one hand, such a de-

Journal of Globalization Studies, Vol. 9 No. 2, November 2018 92-106

DOI: 10.30884/jogs/2018.02.06 
velopment may seem unsurprising. Plugged into transnational financial and cultural flows, the city-state is exposed to the pressures and ideas that drive food sovereignty movements. If food sovereignty movements are understood as responses to the global corporate food regime, then it is precisely in a place like Singapore that we would expect to find such resistance. On the other hand, as a city-state with scarce farmland, the agricultural sector is miniscule. The Southeast Asian nation imports 90 per cent of the food it consumes. There are few producers and Singaporeans are accustomed to eating food produced abroad. A final complicating factor is that civil society in Singapore is rarely confrontational. While actors express a determination to grow their own food, they do not articulate any direct resistance to the global food system or even to government policies. The values of 'democracy' and 'participation' resonate poorly with public norms in Singapore.

Can a food sovereignty movement emerge without direct resistance and without a base of full-time farmers? If Singapore can be said to have a food sovereignty movement, then where has it come from and what challenges does it face? Not only does the Singapore example provide a unique vantage point for viewing global food struggles, these questions also probe central themes connected to the state's management of globalization. For decades, the state has carefully managed the island's position in financial, production, and labor flows. Creating an environment that is attractive to global firms has been a key part of the state's effort to promote GDP growth, which in turn has been presented as a political pillar of the long-ruling government. Singapore's approach to globalization earns it praise as a model for other countries to follow (Ortmann 2012). A rising diversity of public views on food production implies a questioning of the dominant vision of how global networks can serve Singapore interests.

I argue that there are elements of a food sovereignty movement in Singapore. This movement can be understood as a variation on 'quiet food sovereignty' activism, in which participants engage in subtle rather than direct resistance (Visser et al. 2015). Despite the small number of producers, the lack of overt resistance, and the absence of ties to the global food sovereignty movement, food activists in Singapore articulate a quiet but radical critique of how the state manages globalization. A local context of scant public dissent on the norm of GDP-first makes this critique radical. I point also to two sets of challenges to this movement in Singapore. First, the state's control over resources allows for mainstream visions of agriculture to gain greater support and places food sovereignty activists at the mercy of government. Second, commercial pressures raise obstacles to making farming an attractive vocation or hobby for Singaporeans.

\section{Food Sovereignty: What Makes a Movement?}

Movements for food sovereignty have appeared around the globe. Emerging from farmer activism and consumer demands for more local food options, these movements represent responses to the global food regime. As McMahon points out, 'food sovereignty is ... about confronting globally interconnected relations of power in the present, opening space for new (and old) agro-ecological practices and new, just forms of agri-food governance' (McMahon 2014: 133). This activism is linked through a transnational movement which takes shifting forms around the world. In many analyses, food sovereignty is seen first and foremost as a social movement. Such an approach may highlight activists who build a collective identity and coordinate their activities deliberately. Food sovereignty has been presented as an intentional, conscious 
movement: 'food sovereignty is not just a reaction against neoliberalism, it is a project for the democratization of the food system that also aims to restructure the state and remake the global economy' (Menser 2014: 53). Many studies highlight food sovereignty as a global movement, with groups such as Via Compesina - widely credited with popularizing the term 'food sovereignty' - at the center (e.g., Claeys 2015). However, in less liberal political contexts, it may be impossible or imprudent to raise a direct challenge to authorities over the food system. Can we speak of food sovereignty in such contexts?

Studying food sovereignty as a social movement is not the only approach. The core of food sovereignty may also be understood as opposition to the global food regime. The concern with social control over food production is what distinguishes food sovereignty from food security (Patel 2009: 665; McMichael 2014). Food sovereignty is fundamentally an engagement with corporate control over food production networks. If we begin from this point, then it may be that the food sovereignty critique can take alternative forms. Visser et al. (2015) suggest that 'quiet food sovereignty' movements can occur in societies where social movements are discouraged or not permitted. Their research shows how small-scale farmers in Russia have engaged in behavior that implies a rejection of the global food regime without articulating it as such. In Singapore, where civil society rarely voices strong criticism of the government, the concept of 'quiet food sovereignty' could be relevant. The illiberal atmosphere in Singapore stems partly from controls on speech and organizing designed to prevent communal tensions from rising in this multicultural nation. If food sovereignty can be found in Singapore, it would likely be of this quiet type.

There could be danger in stretching the concept of food sovereignty so far that it includes activities that ought to be understood in different terms. An increasing interest in local food production does not necessarily signal food sovereignty. A local farming movement may not be an engagement with the global food regime. It could be inward looking rather than a critique of a community or nation's position in transnational food networks. Market-oriented local food movements, for example, can lose their political goals and thereby become clearly separate from food sovereignty movements (Andree 2014). While local food systems may operate within the capitalist food regime, food sovereignty movements work against the global food regime (Robbins 2015: 453-454). There can thus be local food systems with food sovereignty claims and those without such claims.

There is more at stake here than food or agricultural production. Food sovereignty relates directly to fundamental questions about who controls responses to exposure to transnational corporate forces. The Singapore economy is based on a particular engagement with such forces, but the state is also extremely powerful. The state brokers the influence of transnational finance and business. It champions a view that relatively unproductive economic activities, such as soil-based farming, make little sense in a context of scarce land. This logic hides a politics which food sovereignty recovers, as McMichael notes in writing more broadly: "Food sovereignty" politicized this naturalized claim for market rationality in global food provisioning' (2014: 937). There is a great deal of difficulty in articulating alternative visions for managing globalization. The push for local agriculture in Singapore can be seen in terms of struggles over basic visions for the city-state's future. 


\section{Agriculture in Singapore}

Singapore is not often associated with agriculture. The city-state is overwhelmingly urban and most residents have no connection to food production. Furthermore, since Singapore was founded as an entrepot city in the nineteenth century, trade and finance were the initial areas of economic focus. However, the Southeast Asian nation does have an agricultural sector, one that at times has been substantial. In the late nineteenth-century, land in Singapore, as in much of southern Malaya, was converted for plantation uses. Palm and rubber plantations accounted for many of these. The peak of the plantation economy came in the 1930s, when almost two-thirds of the land was devoted to production of food and other crops (Neville 1992: 245). Rubber declined sharply in the mid1930s and suffered during the Japanese war-time occupation, not recovering after the Second World War. Between 1945 and the establishment of Singapore as an independent country in 1965, agriculture was oriented to production for domestic consumption. It was in this period that farming, in the sense of growing food for local consumption, was at its peak.

After 1965, farming declined rapidly alongside social and economic projects led by the People's Action Party (PAP) government. The government has long emphasized productivity and specialization (Rodan 1989: 162). These included urbanization of the population in which villagers were shifted into public housing. Planners set out to industrialize the island and to shift land to more productive uses. The government could acquire land and then use it for the purposes it deemed most productive. Agricultural land was acquired and put to other uses in the name of modernizing the economy. Farms were relocated to the north and northeast parts of the island. The shifts were clear. Some 175,400 people were actively engaged in agriculture as late as 1970 (AVA 2015). At that time, agriculture occupied 25 per cent of total land area. By 1988, the land area used for farming was dramatically reduced to three per cent of the country (Ludher 2016).

To the extent that Singapore remained tied to agriculture, the state encouraged agricultural ventures to maximize productivity. In the early 1980s, for example, a meat industry was thriving. The country was self-sufficient in poultry and pork (Templeman and Suykerbuyk 1983: 65). However, the attempts to modernize the pork sector created pollution problems that were not easily resolved. By 1983, the government started to eliminate pork production and later that decade the pig farms had almost completely disappeared (Neville 1992: 249). The government encouraged livestock firms to shift overseas, in particular to Indonesia's nearby Riau islands. There, with more space and lower labor costs - and with fewer concerns about pollution - the pork industry could be more productive. Furthermore, by being located nearby, these firms ensured an emergency supply of meat to Singapore. In the 1990s, the state pushed for upgrading in other areas of agriculture. Just as in planning of industry, agriculture was to be done efficiently if done at all. Government agencies supported capital-intensive agriculture and helped with the establishment of agri-parks designed to spur technological development in the sector (Neville 1992: 249-252).

Singapore today imports 90 per cent of its food. Only one per cent of total land is used for farming purposes, supplying eight per cent of vegetables, eight per cent of fish and 26 per cent of eggs consumed in Singapore today (Lim 2009; Trading Economics 2016). Singapore's commercial farming sector includes some 100 farms clustered in 
Kranji, in the northwest of the island. The official view on local agriculture continues to be that it should be productive in a way that contributes to GDP growth. This priority suggests a preference for capital-intensive farming and for investment in the development of agricultural technologies that can be exported. Perhaps surprisingly, Singapore offers technical assistance in the area of agriculture to neighboring countries - all of whom have far more experience with growing food. It is because of research and development in agricultural technology that Singapore can play this role. In addition to productivity, a secondary emphasis in the official view stems from concerns about food security. Growing food locally is a strategy - usually a minor one - for ensuring access to a stable supply of food for local consumption.

\section{Food Sovereignty, Singapore Style}

To speak of food sovereignty in Singapore can seem odd. The language and style of global food sovereignty activist networks is a poor fit with the orderly city-state. When Singapore hosted an International Monetary Fund (IMF) meeting in 2006, activists with Via Campesina were detained and deported. Food sovereignty, though, need not be directly confrontational. The term encompasses many perspectives and activities. As Patel notes, 'food sovereignty is a big tent' (2009: 666). Other researchers point more to tensions within the concept of food sovereignty (Edelman 2014). There is no need to expect that food sovereignty movements take the same shape everywhere.

The last decade has seen a surge in interest in local food production. Part of this interest stems from consumers who are concerned about food safety and health. Imported from overseas, food products are not produced under conditions the Singapore government can regulate. Vegetables and fruits come from China, Malaysia, Vietnam, Indonesia, and other locations in Southeast Asia, and Australia. The overuse of pesticides and chemical fertilizers in some of these places is well known. The safety of imported produce has increased consumer interest in organic of local options. In addition, government campaigns to encourage people to make healthy food choices have contributed to demand for organic foods. Many organic products in Singapore come from overseas and are expensive. Locally-grown organic greens are closer in price to conventional greens. In neighborhood supermarkets, sections selling local organic produce have expanded. For these consumers, the interest in local agriculture comes not from an innate interest in food production but from these concerns about health and food safety, and local, organically-labeled produce offers the most affordable alternative. Ideas about healthy and local eating may arrive in Singapore from global consumption trends. The island is well-connected to consumer culture overseas and consumer preferences may come through the numerous Singaporeans who work or study abroad and through the large expatriate population.

More closely connected to food production, an increasing number of farmers, weekend gardeners, and activists have encouraged Singaporeans to take a greater interest in how food is grown. Several organizations have emerged that are committed to local, ecologically-friendly modes of agriculture. These organizations rarely make statements that are directly critical of government or even of status quo views of agriculture. There is also a range of reasons given for stressing food production. What joins these groups and gives them features of a food sovereignty movement is that they argue there is intrinsic value in producing food for oneself and one's community. The activities and 
visions of the organizations in this movement highlight this commonality. I now introduce some of these activists.

\section{Farm associations}

The Kranji Countryside Association, founded in 2005, is a nonprofit group made up mostly of farmers located in the northwest part of the island. Many farms in their area are open to visitors; the association helps promote the farms. The association operates the Kranji Countryside Farmers' Market, which has been held every three or four months since 2014. The Farmers' Market has 8,000 to 10,000 visitors (Said 2016). This event is one of the most important for generating public interest in local farms. These activities serve the commercial interests of the farms and they also encourage Singaporeans to find meaning - or at least entertainment - in being close to agricultural sites.

The youth wing of the Kranji Countryside Association is called Singapore Young Farmers. Its founders are the children of commercial farmers and they are dedicated to building futures in the field. The group operates outreach programs. Its aims are summarized as follows:

We hope to foster a farming community among the youth in Singapore. Youth today are often disconnected from the role that agriculture plays in their lives because of supermarket convenience and mass consumption. We want to inspire the next generation of change-makers to connect back to the rustic countryside, with these goals: \#1 Increase awareness of local farms, and understanding their importance; \#2 Position local agriculture as a young, fun and innovative industry; \#3 Connect youth to the countryside, and engage them in meaningful activities; \#4 Provide leadership and opportunities for youth to practice and excel in the area of agriculture. ${ }^{1}$

In the Singapore context, this vision is nearly rebellious. The group's organizers are university-educated and by choosing to work in agriculture they have made antiestablishment decisions. Not only that, but they urge other Singaporeans to find value in producing food rather than in consumption. In a country where young people are encouraged to seek the highest-paying jobs they can, the aims of this group stand in sharp contrast to official values.

\section{Community groups}

Other nonprofits are not connected to commercial farms. An example is Farmily, a charity set up by a polytechnic student in 2011. The organization brings elderly people together to grow organic vegetables. It uses food production as a way of addressing the issues of an aging society. 'We are dedicated to support [the] local food production system, enable communities to enjoy locally grown fresh produce, build a healthier community and an environment that fosters social interactions, and lastly promoting a just and sustainable food system,' the Facebook page announces. ${ }^{2}$ Community is a value that comes from farming, according to this organization.

Farmily is nested within the Ground-Up Initiative (GUI), another nonprofit community organization. Founded in 2008, GUI is a citizen-organized space for community activities. It engages in education and in environment-related initiatives in particular. It 'is a volunteer-driven non-profit community that values connecting with the land for the many things it teaches us. ${ }^{3}$ The founder is inspired by Chinese philosophies. He 'believes that ownership and responsibility towards society comes with understanding 
our inherent symbiotic connection to our environment. The more we are nurtured spiritually and psychologically by it, the more we will understand how important it is to conserve this inspiring life-giving force. ${ }^{4}$ Here we see the view that being connected to nature and growing are meaningful activities.

For these nonprofit groups, local production - above productivity - is of inherent value. Their interests are not mostly in the market logic. Rather, they point to the intrinsic value to individuals and communities of getting close to the production process. They represent some of the newest voices in Singapore's food production circles.

Rooftop gardeners and landscape designers

Another set of new, city-based organizations has business models based on sale of produce itself. Comcrop, for example, operates an aquaponics garden in central Singapore. From there the firm supplies herbs and vegetables to nearby hotels and restaurants. Aquaponics is attractive, the director claims, in order to keep labor costs down (Wee 2015). Located atop a mall, G.R.E.E.N.S. is another small enterprise that grows herbs and vegetables. The organization participates in farmers' markets. The founders say they set up G.R.E.E.N.S. partly out of concern with 'reducing our environmental footprint. We are strong believers that good food is not just something that is reserved for the wealthy, but a basic human right. In our explorations, we have discovered the joy of growing herbs, and have spent the last few years curating, and producing small quantities of delicious herbs. ${ }^{5}$ The mission of these organizations is to bring consumers closer to food production.

Private firms specializing in garden design or advice have recently come on the scene. Many of these firms have multiple tasks. Edible Garden City, for example, is a firm organized around individuals committed to organic farming. It mostly designs vegetable gardens for commercial clients, such as hotels or restaurants or public facilities. The founder, Bjorn Low, is a former marketing executive who left the rat race to engage in farming. Other staff specialize in horticulture or construction. Many have overseas experience. Besides designing gardens, the organization tries to educate the public about organic farming. It holds workshops and works with schools.

A farmer in Edible Garden City explains why he does this work: 'It is my way of connecting with my neighbours through doing something meaningful together... When we grow something as basic as our own food and are sustained by it, we find a personal connection to the place they grow in' (Farm in the City 2015). Farming relates not just to health but to connecting with nature and with community. The Edible Garden City mission takes up this theme: 'We believe that growing food re-connects urbanites to nature, conserves natural resources, and cultivates a sense of community. ${ }^{6}$

UGrow Gardens, founded in 2013, also designs gardens for clients. The founder, James Lam, notes that 'Chefs and homeowners want fresh produce for their kitchens. Companies use the gardens to help their staff relieve stress. It is also a good way to promote community bonding and for neighbours to get to know one another' (Wee 2015). Community-building thus appears as a key theme.

In the Singapore context, the views espoused by these actors are more radical than they might be elsewhere. By finding intrinsic value in production processes, they challenge the GDP-first ideology promoted for decades by the island's leadership. There is no doubt that these actors have many differences with full-time farmers elsewhere in the world who are engaged in movements for food sovereignty. These activists make no 
explicit demands on government or on businesses. They do not articulate their missions in terms of rights or democracy or even 'sovereignty.' Doing so might incur anger from the authorities and would not win sympathy from most residents. It makes more sense to carry out advocacy quietly. Nonetheless, these activists reject status quo views on the role of agriculture and the purpose of economic activity, and they urge ordinary people to find ways of becoming closer to food production.

\section{State Resources and Contending Visions of Local Agriculture}

Food activists in Singapore face special challenges. The state has resources that can shape the abilities of agri-food actors to pursue their visions of local agriculture. Trade policy, for example, clearly influences chances for local producers. In Singapore, the policy of importing nearly all food means, of course, that local producers must compete against goods coming from outside. In three other policy areas, the Singapore state's involvement is also notable. First, the state offers incentives to promote agricultural and agri-food technology enterprises. These incentives can support certain types of firms while discouraging other types. Second, the state's control over land has implications for who has access to land for food production. Third, community support programs also intersect with local food activism. Here I examine how state involvement in each of these three areas impacts opportunities for the contending visions of local agriculture.

Promoting capital-intensive agricultural technologies

The Agri-food and Veterinary Authority (AVA) regulates food and food production in Singapore. Its concerns are with ensuring an adequate food supply, food safety, and promotion of agricultural and food processing industries. The AVA also works to develop the local agriculture sector. This function is not one of regulation but of industry sponsorship and promotion. The AVA oversees agri-tech initiatives and is involved in several agritech parks. It also coordinates with the fish processing industry. The goal in these initiatives is to promote these sectors for overseas growth. They are involved in production of food and farming technologies that can be lucrative in overseas markets. Interestingly, even though Singapore hardly produces food for itself, the food regulator is involved in agricultural ventures aimed at overseas markets. Singapore even gives technical assistance in the area of agriculture. It may seem strange for agricultural countries to gain advice from a non-agricultural one.

An example of one of the technology-focused agricultural sector firms supported by AVA is SkyGreens. The organization designed and produces a rotating, water-driven, low carbon vertical farm. These 'skyfarms' meet several needs. Using the same daily electricity as a light bulb, the towers are energy efficient. The hope is they can help shift agriculture to a lower-energy model. Also important, the towers require little space. They need no soil and, being vertical, they make the most out of the land they occupy. They can be placed on rooftops, for example. This could make them useful in a variety of cities. There are 120 towers in operation and they supply leafy vegetables to the island's largest supermarket chain. The founder, Jack $\mathrm{Ng}$, is an engineer. He explains why this initiative is important in the Singapore context: 'money (is) worthless without food... That's why I wanted to use my engineering skills to help Singapore farmers to produce more food' (Seneviratne 2012). The venture has the financial support of the AVA. 
Besides the local goal of increasing food supply, SkyGreens has a far broader aim. Clearly, profits from spinach are insufficient for a firm that has invested so much. The firm 'endeavours to becoming the world leading solution provider for integrated, sustainable and green urban agriculture technology.' It also wants to 'help cities actualise food supply security and food safety targets" and "promote and enable seamless integration of low carbon footprint agriculture into urban living. ${ }^{7}$ SkyGreens plans to produce their towers for export at a price of SGD \$10,000 each (Krishnamurthy 2014).

As these statements reflect, concerns about both food security and about productivity drive Ng's project. Growing food locally can address the issue of food security. Using capital intensive measures is an effort to make agriculture productive. It means using less space and less manpower. Finally, by offering the possibility of exporting the technology, the initiative may make Singapore's agricultural technology globally competitive. This example points to the government's view of the future of the agricultural sector in Singapore. Its focus is on creating exportable technologies for soil-free farming, an aim far removed from bringing people close to nature.

Moreover, the emphasis on technology has come to dominate public discussion of local agriculture. 'Local agriculture' has come to indicate efficient, high tech production of lettuce rather than the community-building, meaningful activities undertaken by soilbased farmers. The term is discussed this way in the news. Technological solutions are also presented at urban farming festivals. Such festivals have become increasingly common in the city-state. These events feature stalls for those selling homegrown produce stand alongside vendors displaying industrial soilless garden equipment.

\section{Land control}

Besides helping cultivate particular agribusinesses, the AVA also shapes local farming through the government's control of land. The state's function as a landlord is exercised through the Singapore Land Authority. Most land is held on lease rather than owned by individuals or organizations. The government can choose not to renew leases and can purchase properties at below-market rates. Farmers are thus at the mercy of the government. The state has enormous leverage over agriculture because of its control over land.

Where farmers have been successful, they have relied on government support for land access. Persistent local individuals succeeded in convincing the government to lend needed support to local food production. Ivy Singh of Bollywood Veggies worked closely with ministries in order to have regulation on local farming changed a decade ago. Success in this endeavor was crucial for her business and the Kranji farmers in her community. The founder of Ground-Up Initiative, too, had two years of negotiations with the government in order to secure a lease. Without the lease - which was completely at the government's discretion - GUI would have remained tiny. In these ways, government decisions have been important in helping groups dedicated to bring people closer to the production process.

The state's control over land, though, means that it can squeeze land-based farming initiatives. The impending fate of the Kranji farmers and their community demonstrates this point. In 2014, the AVA informed the farmers in a large section of Kranji that their leases would expire in a few years. This move affects 62 farms, some of which are over 100 years old. The land is instead to be used for military training, after land set aside for that purpose was marked for development into a new residential town. 
Farmers in Kranji had devoted their lives to these farms and had not built alternate careers. A new area would be set aside for farming but it is smaller and farmers will need to bid against each other for space. Successful new tenants will also be given leases of only ten years, which is a short time for agricultural ventures to turn a profit. This process introduces competition when there had previously been community. The community that had been built in the past decade under the Kranji Countryside Association is thus in danger of being destroyed.

A frog farmer named Chelsea Wan, also founder of the Singapore Young Farmers association, responded to this episode: 'We decided we're not going to bid. We should not be going against each other. We are all friends and now they want us to do this. Just close lah, do not do anymore... Farming has been my first and only job for ten years. I'm already past 30. If I were to look for a job, I don't know where my expertise is besides running around' (Ong 2016). These comments point to the consequences of the shift for individuals and for the community that has emerged.

The vulnerability here is on a scale different from other contexts. While farmers elsewhere might demand government subsidies or import protections, such measures are not even part of the discussion in Singapore. Local producers compete directly against imports from lower-income neighboring countries with no government support. And they can have their land appropriated. This condition imposes real limits on local producers and the local food movement.

A policy of closing down local farms and supporting 'skyfarms' fits easily with mainstream public policy in Singapore, even if it undercuts the emerging local food movement. Singaporeans have long heard arguments about securing food for Singapore and about only supporting productive industries. For example, Lee Sing Kong, Director of the National Institute of Education, supports the official vision of agriculture in Singapore: given 'natural disasters such as flooding, which could impact food production, it may be necessary for Singapore to look at producing some of its own vegetables from the food security point of view.' He envisions indoor farming facilities called 'vegetable factories' in which food supply needs can be productively met (Seneviratne 2012).

\section{Community activities}

In recent years, the state has offered support for farming and gardening activities oriented to community building. These are part of a wider effort to build community (Cho and Kriznik 2017). National Parks' Communities in Bloom program is one example. This program encourages people to start community gardens. This initiative is not specific to cultivating edible produce, but it includes herb and vegetable gardening as a component. It is not a simple process as it requires coordination with three agencies: the Residents' Committee, National Parks, and the Town Council. Many groups have had applications approved and there are now over 1,000 community gardens in operation. The purpose is to foster community and 'civic ownership.' This purpose is also linked to building ties between members of distinct ethnic communities: 'Especially in our multi-ethnic society, community gardens nurture the values of cooperation, volunteering, respecting diversity and creating ecological awareness. ${ }^{8}$ This view of growing resonates with some of the motives of local food activists.

Another instance of government involvement is the establishment of a farmers' market. In 2016, the Central Singapore Community Development Council began holding a farmers' market once per month. The market operates as one of the council's pro- 
grams aimed at promoting 'healthy lifestyle.' As the council website states, the market is 'a platform to encourage healthy eating among our residents, especially cosmopolitan young adults. ${ }^{, 9}$ Farmers' markets are crucial to local growers. At farmers' markets residents also gain exposure to fresh local food. While Singaporeans shop regularly at outdoor grocery markets ('wet markets'), the produce on sale is overwhelmingly of foreign origin. Farmers' markets are among the few opportunities for Singaporeans to try locally-produced goods and to come into direct contact with producers. Such experiences were rare until recently.

\section{Commercial Pressures and Visions for Local Agriculture}

The demands of making agri-food businesses viable also shape opportunities for a food sovereignty movement. How does making a living shape the positions of farmers? As businesses, Singapore's land-based farms face pressures to keep costs down. Commercial agriculture in Singapore follows many of the practices in other areas of manual work. As in construction and manufacturing, commercial farms rely on low-skill foreign labor. These workers come from other parts of Asia, usually through the introduction of agents, and stay in the city-state on short-term work passes. The availability of this workforce shapes farm management. Labor is so inexpensive that it does not need to be deployed carefully. A walk through the agricultural areas of Kranji drives this point home. Around the fields, extra equipment and rubbish are scattered about. At one site, I observed three shirtless young men ploughing a field. Each used a hand plough. One plodded barefoot through the soil, a cigarette dangling from his lips. The similarities between farm and factory management are made more obvious by the geographic proximity of these types of enterprises. Kranji has both farms and factories. Trucks and other heavy machinery are common sights on the roads. Farms rarely use large farmspecialized equipment such as tractors. Instead, they use the same vehicles as the factories do. When a truck comes down the road, it is anybody's guess whether it is serving an agricultural or industrial business.

In these places, one senses the gap between farm work and the lifestyle expectations of most Singaporeans. In an environment of abundant, inexpensive foreign labor, farms are under pressure to assimilate management practices that make agriculture labor intensive. Given this situation, it makes little economic sense to manage farms in a way that would valorize farm work. It is difficult to make agriculture attractive as an occupation in this context. Manual labor has long been treated as undesirable in Singapore, and convincing people that such work is respectable is a hard sell. If wages were allowed to rise and productivity as well, the situation might be different. While a growing number of Singaporeans have chosen to find value in farm work, the country's labor regime creates economic incentives for farms to treat agricultural work as something that 'others' do as cheaply as possible. This factor discourages people to support food sovereignty visions.

The perception of farm work is captured in an anecdote I heard. A dairy farmer from the only such establishment in Singapore - told me about his experience going to the bank for a loan. His family has operated a goat farm for many years. When he went to the bank and told the staff that he was a farmer, she did not understand what he was saying. The appearance of a 'farmer' at the bank was so unfamiliar that the banker needed time to understand.

Food activists who do not operate farms are not subject to the same pressures. An important segment of this group earns a living through supplying services. Some of the 
most vocal participants in the local food movement fall into this category. Committed growers staff Edible Garden City, but food production does not sustain the organization. Instead, it is through offering design services to restaurants, hotels, and other firms, as well as providing team-building experiences to businesses that it earns revenue. Horticulturalists are in a similar position, as they make a living through landscape design. These actors, while committed to generating interest in local food production as a valuable activity in itself, are tied through their economic interests to an elite corporate culture. Many of these activists come from professional backgrounds and have the skills and networks to earn a living this way. Their message is a critique of these forces, but high-end business also pulls them in. This situation is distinct from peasant-led food sovereignty movements. The links between these activists and the global elite consumer culture can also leave an impression on other Singaporeans. That impression is that agriculture is only something that the privileged can do in their leisure time.

These pressures on commercial farms and on service-oriented food activists can thus both make farming look like an unattractive or non-viable option. Commercial farming is not glamorous because there will always be incentives to hire discounted labor for the hard work. Meanwhile, vocal advocates of local farming may be perceived as only being able to take engage in such advocacy because they make a living from their links to elite consumer culture.

\section{Conclusion}

Singapore is home to an emerging movement for local production of food as a value in its own right. This movement has multiple bases. It includes groups of farmers who have staked their livelihoods in agriculture and are committed to doing agriculture in a particular way. It includes NGOs that encourage community building and selfreliance. And it includes social enterprises that attempt to shift people's values. This movement faces considerable challenges because of the resources that can be mobilized to support other visions of local agriculture. In these other visions, such as the government's, local agriculture should be a productive activity that is set within global capitalist flows, not against them. What we see from the Singapore case is that it is not simply the power of the global food regime nor the state as an abstract strong entity that creates challenges for the movement. Rather, the main barriers are the existence of an established orthodoxy about agriculture alongside specific state tools (e.g., land policy and targeted support for agricultural firms) for allocating resources. This combination allows the state to make powerful claims about what sort of agriculture is desirable and what is not.

The food sovereignty movement suggests a deep critique of the Singapore state's entanglement with globalization. The government has prided itself on using GDP growth to deliver a good economy. The logic is that GDP growth, achieved through becoming enmeshed in transnational flows, should come before all other priorities. The food movement suggests that the priorities should be re-thought. That is, it challenges a normative pillar of the state. The movement is a quiet one, but it has implications for thinking about the legitimacy of the state.

The agricultural activities of a small number of a people in a 'global' city-state point to a particular type of politics, one that is relevant well beyond the Southeast Asian nation. This politics is subtler than one of contestation and repression. A state that seeks to maintain society's exposure to global economic flows - no matter what the 
backlash - has many tools it can use. An important set of these are normative. While the link between economic growth and state legitimacy is especially pronounced in Singapore, this logic is increasingly ubiquitous. Societies around the world have lost resistance to the tantalizingly simple idea that what is good for GDP growth is good for society. Appeals to this logic now look less ideological than commonsensical. Such appeals can undermine resistance to global economic networks, such as food production networks. They make it difficult to articulate distinct visions of the common good. When linked with basic state tools, such as land policy and industrial policy, these appeals can be powerful. Singapore's example places in stark relief a claim that is made in many places: when resources can be used more efficiently if allocated to a certain purpose, then they ought to be used that way. This claim is presented in apolitical terms, even as it serves a political purpose. Projects to reassert local or community control over basic aspects of life, such as food, face the difficult challenge of countering a proglobalization state that normalizes efficiency.

\section{NOTES}

${ }^{1}$ Singapore Young Farmers website. http://www.sgyoungfarmers.com/aboutsyf/.

${ }^{2}$ https://www.facebook.com/pg/farmilysg/about/?ref=page_internal.

3 Ground-Up Initiative Facebook page. https://www.facebook.com/pg/groundupinitiative/ about/?ref=page_internal.

${ }^{4}$ Ground-Up Initiative website. http://groundupinitiative.org/.

${ }^{5}$ G.R.E.E.N.S. Facebook page. https://www.facebook.com/pg/greens.in.sg/about/?ref=page_internal.

${ }^{6}$ Edible Garden City website. http://www.ediblegardencity.com/about/.

${ }^{7}$ SkyGreens website. https://www.skygreens.com/about-skygreens/.

${ }^{8}$ National Parks. 2015. What is a Community Garden. Official website. https://www.nparks. gov.sg/gardening/community-gardens/what-is-a-community-garden.

9 Central Singapore Community Development Council website. https://www.cdc.org.sg/ CentralSingapore/Programmes/Healthy_Lifestyle/Farmers_Market.

\section{REFERENCES}

Andrée, P., Ayres, J., Bosia, M. J., and Massicotte, M.-J. 2014. Food Sovereignty and Globalization: Lines of Inquiry. In Andrée, P., Ayres, J., Bosia, M. J., and Massicotte, M.-J. (eds.), Globalization and Food Sovereignty: Global and Local Change in the New Politics of Food (pp. 23-52). Toronto: University of Toronto Press.

Andrée, P. 2014. Citizen-Farmers: The Possibilities and Limits of Australia's Emerging Alternative Food Markets. In Andrée, P., Ayres, J., Bosia, M. J., and Massicotte, M.-J. (eds.), Globalization and Food Sovereignty: Global and Local Change in the New Politics of Food (pp. 141-172). Toronto: University of Toronto Press.

AVA. 2015. Singapore's Food Farms: A Story of 'Then and Now'. Issue 4. URL: http://www.ava.gov.sg/files/avavision/issue4_2015/sg50_special.html.

Cho, I., and Kriznik, B. 2017. Community-Based Urban Development: Evolving Urban Paradigms in Singapore and Seoul. Singapore: Springer.

Claeys, P. 2015. Food Sovereignty and the Recognition of New Rights for Peasants at the UN: A Critical Overview of La Via Campesina's Rights Claims over the Last 20 Years. Globalizations 12 (4): 452-465. 
Di Dio, D. 2012. Global and Local Drivers in the Globalization of Food Industry: The Case of Milk Powder. Journal of Globalization Studies 3 (2): 155-165.

Edelman, M. 2014. Food Sovereignty: Forgotten Genealogies and Future Regulatory Challenges. The Journal of Peasant Studies 41 (6): 959-978.

Farm in the City... 2015. Farm in the City: Edible Landscape. Straits Times, February 8. URL: http://www.straitstimes.com/lifestyle/farm-in-the-city-edible-landscape.

Grinin, L. 2012. New Foundations of International System or Why Do States Lose Their Sovereignty in the Age of Globalization? Journal of Globalization Studies 3 (1): 3-38.

Herrera, R. et al. (ed.). 2015. The Struggle for Food Sovereignty: Alternative Development and the Renewal of Peasant Societies Today. London: Pluto Press.

Krishnamurthy, R. 2014. Vertical Farming: Singapore's Solution to Feed the Local Urban Population. Permaculture News, July 25. URL: http://permaculturenews.org/2014/07/25 vertical-farming-singapores-solution-feed-local-urban-population/.

Lang, T., and Heasman, M. 2004. Food Wars: The Global Battle for Mouths, Minds and Markets. London: Earthscan.

Lim, J. 2009. Farmlands in Lim Chu Kang. Singapore Infopedia: National Library Board. URL: http://eresources.nlb.gov.sg/infopedia/articles/SIP_1611_2009-11-30.html.

Ludher, E. 2016. Singapore's Smart Governance of Food. In Deakin, M., Borrelli, N., and Diamantini, D. (eds.), The Governance of City Food Systems: Case Studies from around the World (pp. 131-148). Milan: Fondazione Giangiacomo Feltrinelli.

McMahon, M. 2014. Local Food: Food Sovereignty or Myth of Alternative Consumer Sovereignty? In Andrée, P., Ayres, J., Bosia, M. J., and Massicotte, M.-J. (eds.), Globalization and Food Sovereignty: Global and Local Change in the New Politics of Food (pp. 111-140). Toronto: University of Toronto Press.

McMichael, P. 2014. Historicizing Food Sovereignty. The Journal of Peasant Studies 41 (6): 933-957.

Menser, M. 2014. The Territory of Self-Determination: Social Reproduction, Agro-Ecology, and the Role of the State. In Andrée, P., Ayres, J., Bosia, M. J., and Massicotte, M.-J. (eds.), Globalization and Food Sovereignty: Global and Local Change in the New Politics of Food (pp. 53-83). Toronto: University of Toronto Press.

Navin, M. C., and Dieterle, J. M. 2018. Cooptation or Solidarity: Food Sovereignty in the Developed World. Agriculture and Human Values 35 (2): 319-329.

Neville, W. 1992. Agribusiness in Singapore: A Capital-Intensive Service. Journal of Rural Studies 8 (3): 241-255.

Ong, J. 2016. Unanswered Questions, Uncertain Future for Kranji Farmers. Channel News Asia, May 28. URL: http://www.channelnewsasia.com/news/singapore/unansweredquestions/2823076.html.

Ortmann, S. 2012. The 'Beijing Consensus' and the 'Singapore Model': Unmasking the Myth of an Alternative Authoritarian State-Capitalist Model. Journal of Chinese and Economic and Business Studies 10 (4): 337-359.

Patel, R. 2009. Food Sovereignty. The Journal of Peasant Studies 36 (3): 663-709.

Robbins, M. J. 2015. Exploring the 'Localisation' Dimension of Food Sovereignty. Third World Quarterly 36 (3): 449-468.

Rodan, G. 1989. The Political Economy of Singapore's Industrialization: National State and International Capital. London: Palgrave Macmillan. 
Said, N. 2016. Kranji Farms Is Now an Official Point of Interest and This Has Given the Farming Cluster a New Appeal. Straits Times, April 8. URL: http:/www.straitstimes. com/lifestyle/farm-hopping-in-kranji.

Seneviratne, K. 2012. Farming in the Sky in Singapore. InterPress Service, December 12. URL: https://ourworld.unu.edu/en/farming-in-the-sky-in-singapore.

Templeman, G. J., and Suykerbuyk, F. J. J. 1983. Agriculture in Singapore: Problems of Space and Productivity. Singapore Journal of Tropical Geography 4 (1): 62-72.

Trading Economics. 2016. Agricultural Land Percent (Singapore). URL: http://www.tra dingeconomics.com/singapore/agricultural-land-percent-of-land-area-wb-data.html.

Visser, O., Mamonova, N., Spoor, M., and Nikulin, A. 2015. 'Quiet Food Sovereignty' as Food Sovereignty without a Movement: Insights from Post-Socialist Russia. Globalizations 12 (4): 513-528.

Wee, L. 2015. Urban Farms Taking off All Over Singapore. Straits Times, February 8. URL: http://www.straitstimes.com/lifestyle/urban-farms-taking-off-all-over-singapore. 